International Journal of Automotive and Mechanical Engineering ISSN: 2229-8649 (Print); ISSN: 2180-1606 (Online);

Volume 14, Issue 1 pp. 4068-4079 March 2017

CUniversiti Malaysia Pahang Publishing

DOI: https://doi.org/10.15282/ijame.14.1.2017.18.0328

\title{
Archachatina marginata bio-shells as reinforcement material in metal matrix composites
}

\author{
M.Y. Kolawole ${ }^{1 *}$, J.O. Aweda ${ }^{2}$ and S. Abdulkareem ${ }^{2}$ \\ ${ }^{1}$ College of Engineering \& Technology, Department of Mechanical Engineering, \\ Kwara State University, Malete, Nigeria \\ ${ }^{2}$ Faculty of Engineering \& Technology, Mechanical Engineering Department, \\ University of Ilorin, Nigeria \\ *E-mail: maruf.kolawole@kwasu.edu.ng
}

\begin{abstract}
Snail shells $\left(\mathrm{S}_{\mathrm{n}} \mathrm{S}\right)$, which represent the discarded bio-shell waste of snails' remnants from restaurants and eateries constitute a serious degree of environmental threat with little or economic value. The effective utilisation of this waste into a green metal matrix composite as a low cost reinforcement material applicable in the automotive industry in lieu of its present hazardous impact had stimulated the research interest. Hence, this paper studies the potential utilisation of $\mathrm{S}_{\mathrm{n}} \mathrm{S}$ as a low cost reinforcement material in the metal matrix composites (MMCs) by means of a characterisation technique. The mineralogical composition and physical properties of the snail shell powder was carried out using the density determination, thermogravimetric analysis (TGA), refractoriness, energy dispersive X-ray (SEM/EDX), X-ray fluorescent (XRF) and the X-ray diffraction (XRD) analysis at $0,800,850$ and $900{ }^{\circ} \mathrm{C}$ calcined temperatures for $3 \mathrm{hrs}$. The results obtained show that the snail shell powder possesses chemical hard phase oxides $\left(\mathrm{CaO}, \mathrm{Fe}_{2} \mathrm{O}_{3}\right.$, $\mathrm{Al}_{2} \mathrm{O}_{3}, \mathrm{Cr}_{2} \mathrm{O}_{3}, \mathrm{SiO}_{2}, \mathrm{MnO}$ and $\mathrm{NiO}$ ) at all calcined temperature values. The maximum amount of these phases was formed at a $900{ }^{\circ} \mathrm{C}$ calcined temperature. The XRD analysis also confirmed the presence of calcite $\left(\mathrm{Ca}_{6} \mathrm{C}_{6} \mathrm{O}_{8}\right)$, lime $\left(\mathrm{Ca}_{4} \mathrm{O}_{4}\right)$ and portlandite $\left(\mathrm{CaO}_{2} \mathrm{H}_{2}\right)$ as the thermally stable major hard phases of the $\mathrm{S}_{\mathrm{n}} \mathrm{S}$ calcined at $900{ }^{\circ} \mathrm{C}$. The density and refractoriness temperature of the snail shell powder as obtained in this study are 1.63 $\mathrm{g} / \mathrm{cm}^{3}$ and $1400{ }^{\circ} \mathrm{C}$. The TGA result shows that the $\mathrm{S}_{\mathrm{n}} \mathrm{S}$ attained its thermal stability at $840^{\circ} \mathrm{C}$. The above results imply that $\mathrm{S}_{\mathrm{n}} \mathrm{S}$ with (9.4-25.9) \% lesser density when compared with agro or industrial wastes reinforcement material (flyash, coconut shell ash, maize husk, bagasse) in the metal matrix composite looks promising as a reinforcing material in the production of light weight metal matrix composites at low costs. Also, the high refractoriness temperature of the snail shell particle suggested it as a suitable candidate reinforcement material in the production of thermal resistance MMCs applicable in automotive components such as pistons and connecting rods.
\end{abstract}

Keywords: Bio-waste; snail shell; metal matrix composites; reinforcements; mineralogical characterisation.

\section{INTRODUCTION}

The limited availability and high cost of commonly used synthetic reinforcement material in metal matrix composites (MMCs) had hindered the industrial production of MMCs on a large scale for instance, in the automotive industry [1-6]. Thus, researchers are now focusing on the use of industrial and agro allied waste products 
as an alternative source of reinforcement materials in the MMCs production at low costs that are future assured as a way out of the current limitation. Most of these wastes are borne out of the increasing human population and activities which had resulted in the generation of colossal wastes without a viable economic benefit as well as disposal challenges and environmental threats. A crystal clear fact of such evidence of wastes in Nigeria and other tropical regions of the world are snail shells [7]. The increasing demand for snail meat in Nigeria and other parts of the world due to its nutritious and medicinal benefits has cumulated in the over swelling of dumping sites with discarded snail shells thus resulting in environmental hygiene challenges $[8,9]$. Snail shells are remnants of snail animals usually discarded after the removal of the snail flesh from the shells as a by-product of domestic households, restaurants and eateries. They are largely available in most humid tropical forests of West African countries including Nigeria and are eaten in different parts of the world [7]. Joshua et al. noticed that the arbitrary discarding of these wastes had caused several degrees of injuries in children with environmental pollution. Hence, there is a need to reclaim these bio-shell wastes for further processing into green technological products/material, such as metal matrix composites for viable economic value.

Metal Matrix Composites (MMCs) are an engineered combination of metal (matrix) and hard particles (reinforcement) to produce properties of a desired specification [10-13]. Due to the rapid industrial and technological growth, given the opportunities for various applications, economic and environmental benefits, it is becoming increasingly important to develop material that will have a good strength-toweight ratio suitable for automotive, aerospace and defence applications from industrial, agro and bio-waste resources [14]. These properties are easily achievable with the aluminium alloy based metal matrix composite (AMC) at lower costs [15-18]. The fabrication of an enhanced composite material can be done through the careful selection of proper reinforcement materials having the modulus and stiffness higher than the base metal or alloy materials [19]. Hence, the reinforcement material must have a higher strength and hardness value compared to the continuous soft ductile nature of the matrix phase. Reinforcement materials, which may be metallic or non-metallic (ceramics, agro and bio-waste), can be classified based on geometry into continuous and discontinuous fibre, wiskers or particles reinforcement materials. Rajeshkumar et al. reported that the mechanical properties of MMCs with discontinuous fibre, whisker or particles are not as superior as those of continuous fibre reinforced composites; however, particulate metal matrix composites (PMMCs) have isotropic properties with simple and cost effective production advantages which could be automated. Also PMMCs can easily be tailored for specific applications by varying the parameters thereof such as the particle size, volume fraction, stirring speed and time, melt temperature and solidification rate. The suitability of these particulate materials as a reinforcing phase in the matrix composite fabrication is usually determined via their combined physical and chemical genetic makeup characteristics of such material via the characterisation analysis route.

Research works on the mineralogical characterisation of industrial waste (fly-ash) and agro-waste materials such as sugar cane bagasse ash, coconut ash, bread fruit hull ash, groundnut husk ash, maize husk and rice husk ash as reinforcement material in metal matrix composites have been reported extensively in the literature [1, 20-22]. Their suitability as reinforcement materials were hanged upon the presence of hard phase substances with lighter density characteristics as well as the capability to withstand higher temperature conditions [21]. Atunaya et al. [23] characterised breadfruit seed hull ash for a potential utilisation in the metal matrix composite for automotive application and found 
that it contains hard phase substances suitable for reinforcement materials in the metal matrix composites with thermal resistance properties. A similar result was obtained by Madakson et al., using coconut shell ash. In a similar research work of Ravinder and Harvinder, both treated and untreated rice husk ash and flyash were characterised with the purpose of determining their mineralogical reinforcement properties in the metal matrix composites. The results revealed the presence of hard phase materials in both treated and untreated materials suggesting them for use as reinforcement materials in the metal matrix composite for the wear resistant application. Works on bio-waste shells such as snail shells in MMCs are limited when compared with synthetic material and agrowastes material as reinforcement. Snail shells are bio-waste remnants of domestic households, restaurant and eateries. Nevertheless, there have been some bodies of literature on snail shells used in polymer composites [24, 25]. However, studies on snail shells in the metal matrix composite had rarely been found until recently when the effect of the weight fraction of snail shell particles ranging from 16 to $48 \mathrm{wt} \%$ and grain size of 200, 400 and $600 \mu \mathrm{m}$ on the tensile and hardness properties of aluminium obtained from a discarded aluminium alloy was investigated [26]. However, the result obtained was contrary to the behaviour of most synthetic, industrial and agro-waste reinforcement materials in which the strength and hardness of the reinforced composites increases with the decrease in particle size as revealed by some researchers $[27,28]$. Hence there is a need to carry out the mineralogical properties characterisation analysis for snail shell powder in order to further elucidate its characteristic potentials as reinforcement in the matrix melt for optimum exploration of its application in MMCs. In addition, the particular species of snail shells used was unknown. Hence, the objective of the present work is to characterise the bio-waste of Archachatina Marginata snail shells for potential utilisation in metal matrix composites aimed at obtaining low cost reinforcement materials for the development of automobile engineering components. The successful achievement of this goal as part of an on-going research work will provide stepping stone information on its physical, thermal and chemical make-up properties of $S_{n} S$ which are vital towards selecting optimum processing parameters for the fabrication of metal matrix/ $\mathrm{S}_{\mathrm{n}} \mathrm{S}$ composites for various engineering applications. Amongst other advantages are the economic benefits through foreign exchange earnings and environmental control measure.

\section{MATERIALS AND METHODS}

\section{Material}

The snail shells used in this work are of the Archachatina Marginata species and were obtained in the Abegunde Village, Okitipupa Local Government, Ondo State, Nigeria. Figure 1 shows a pictorial cross-section of the snail shells sample.

\section{Equipment}

The equipment used in this work includes: a carbolite electric furnace (KSL 1500X) with a maximum operating temperature of $1200{ }^{\circ} \mathrm{C}$, a scanning electron microscope with an energy dispersive spectrometer SEM/EDS machine (ASPEX 3020), X-ray fluorescent (XRF-Pananalytical, minipal 4), an Empyrean X-ray diffractometer DY 674 (2010) with $40 \mathrm{~mA}, 45 \mathrm{VA}$ and $240 \mathrm{~mm}$ tube current, voltage rating and goniometer radius respectively and Digital electronic balance (Ohaus, model CS 200, 0-300g). 


\section{Material Processing}

The snail shells were washed with detergent and sundried for seven days. The shells were crushed and ground into powder of $250 \mu \mathrm{m}$, as shown in Figure 1(b). Three amounts of $30 \mathrm{~g}$ each of powdered samples of the snail shell was put in a stainless crucible and fired at 800,850 and $900{ }^{\circ} \mathrm{C}$ respectively in a carbolite electric furnace for three hours.

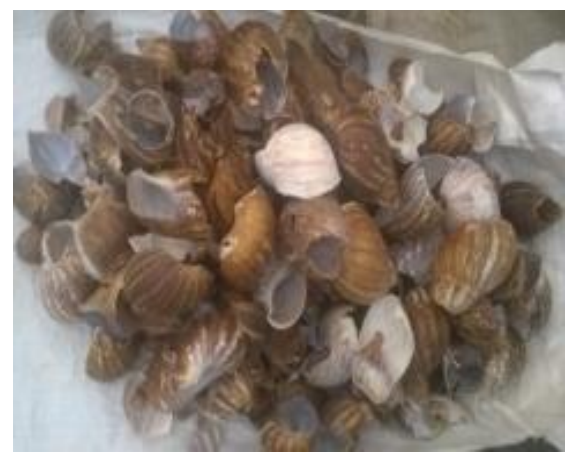

(a)

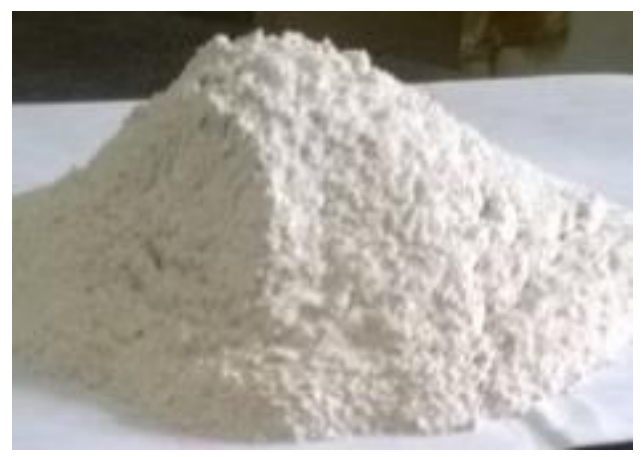

(b)

Figure 1. Snail shells (a) Solid form (b) Powdered form.

\section{Density Measurement}

The density of the snail shell powder was determined using Archimedes' principle as in Usman et al. (2014). This was performed by weighing the shell sample in air using the electronic weighing balance and then immersed in a graduated measuring cylinder to obtain the rise in volume. The rise in volume was then taken and recorded as the weight in water to determine the density.

\section{Thermogravimetric Analysis (TGA/DTA)}

The thermogravimetric analysis (thermal stability and temperature of destruction/burning Tdes) of the snail shell ( $\mathrm{SnS}$ ) powders was carried out at the Institute of Nano and Biotechnology Laboratory, Federal University of Technology Minna Nigeria, using the Perkin Elmer DTA/TGA4000 Thermogravimetric Analyzer at 10 0C/min constant heating rate in nitrogen atmosphere following the ASTM D6370 standard procedure. This was aimed at determining the thermal stability property of the snail shell as a reinforcement material.

\section{Refractoriness}

The pyrometric cone analysis (PCE) as recommended by ASTM C $24-79$ [1] was used to test for the refractoriness of the snail shell. The snail shell powder was prepared into $80 \mathrm{~mm}$ by $20 \mathrm{~mm}$ cylindrical form specimens after wet mixing and compacted using a hydraulic press. The prepared specimens were then air and oven $\left(105^{\circ} \mathrm{C}\right)$ dried for 24 and 48 hours, respectively. It was then transferred and set into the furnace in the way shown in Figure 2. The furnace was heated at a standard heating rate of $5^{\circ} \mathrm{C}$ per minute during which the softening of Orton cone occurred along with the specimen test cone. The corresponding refractoriness temperature of the snail shell sample to the cone number was read out from the ASTM Orton Series. 


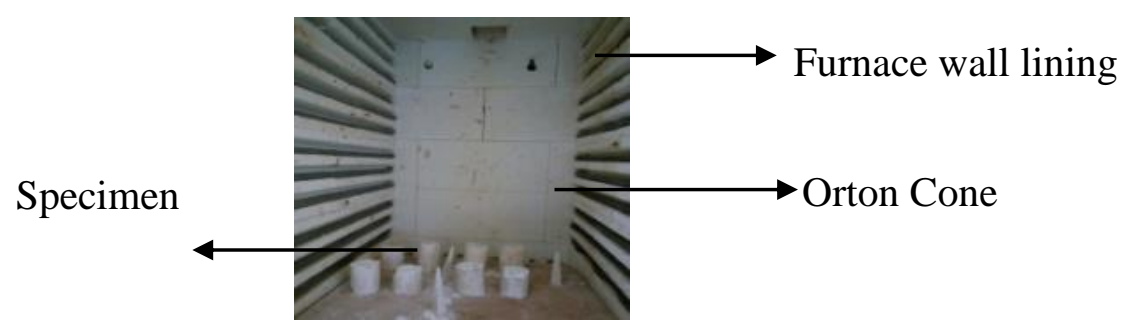

Figure 2. Pictorial view of the test specimen and standard cone (all in the furnace).

\section{Mineralogical Characterisation Analysis}

\section{SEM/EDX Analysis}

Three small samples of the snail shell were cut. Emery cloth of grade size 220, 320 and 400 mounted on the polishing machine was used to polish the specimen to produce a flat and smooth surface of the sample. The polished samples were placed on the sample holder and the images were captured with an ASPEX 3020 scanning electron microscope, model SIRIUS50/3.8 with an attached energy dispersive X-ray spectroscopy (SEM/EDX) machine. The machine was operated at an accelerated voltage of 5 to $15 \mathrm{kV}$ to determine the snail shell powder $(\mathrm{SnS})$ elemental composition.

\section{XRF Analysis}

The X-ray fluorescence analysis of both non and heat treated $\mathrm{S}_{\mathrm{n}} \mathrm{S}$ powder samples prepared into pellets were loaded into the chamber of X-ray fluorescence spectroscopy running at $30 \mathrm{kV}$ to determine the chemical composition and major oxide constituent present in the $\mathrm{S}_{\mathrm{n}} \mathrm{S}$ powder at varying treated temperatures following the ASTM C114 standard procedure.

\section{XRD Analysis}

The XRD analysis of the snail shell powder was carried out using an Empyrean X-ray diffractometer DY 674 (2010) with 40mA, 45VA and 240mm tube current, voltage rating and goniometer radius, respectively. The powdered sample was prepared using the sample preparation block and compressed in the flat sample holder to create a flat, smooth surface. The sample was later mounted on the sample stage in the XRD cabinet. The Xray of $\mathrm{Cu} \mathrm{K} \alpha$ radiations were collimated and directed onto the sample. Then, the snail shell powder sample was analysed using the reflection-transmission spinner stage and Theta-Theta settings scanning range of 4 to 75.000 degrees with a two-theta step of 0.026 at 13.7700 seconds per step. The intensity of the diffracted X-rays is continuously recorded automatically on a chart and the appropriate $(\Theta)$ and $(d)$ values were then obtained as the sample and detector was rotated through their respective angles in line with the description of Madakson et al. [1].

\section{RESULTS AND DISCUSSION}

\section{Determination of Density}

The density of the snail shell powder was found to be $1.63 \mathrm{~g} / \mathrm{cm}^{3}$ from Archimede's principle as discussed above. This value implicates that the $S_{n} S$ powder is a very light material with the tendency of reducing the overall weight of MMCs when incorporated. The value obtained falls below the range of density of fly ash, baggase, bread fruit hull ash, coconut shell ash and silica, which is within 1.8 and $2.2 \mathrm{~g} / \mathrm{cm}^{3}$ respectively, as 
currently used in metal matrix composites [1,23]. This result suggests that the $\mathrm{S}_{\mathrm{n}} \mathrm{S}$ powder may be presumed to be more suitable as a reinforcement material when compared with the weight of baggase, bread fruit hull ash, coconut shell ash and silica in the production of MMCs.

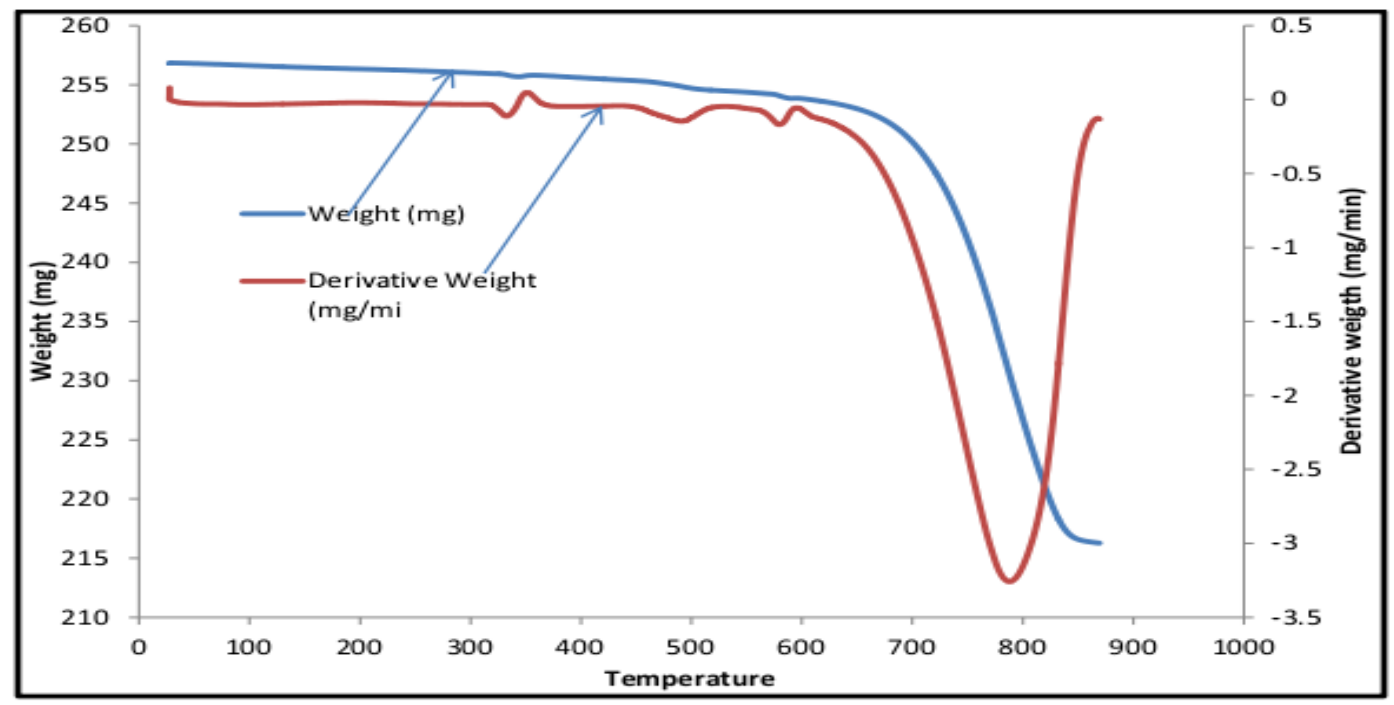

Figure 3. TGA/DTA curve for the snail shell powder.

\section{Thermogravimetric Analysis}

The DTA/TGA curve analysis for thermal stability and the temperature of destruction characteristics of $\mathrm{S}_{\mathrm{n}} \mathrm{S}$ shell powder was illustrated in Figure 3. The thermal stability of the $\mathrm{S}_{\mathrm{n}} \mathrm{S}$ shell powder in terms of weight loss took place in four steps. The first phases corresponded to a temperature range of $27.7-320{ }^{\circ} \mathrm{C}$, where no reasonable degradation of $\mathrm{S}_{\mathrm{n}} \mathrm{S}$ powder was noticed. This implies that the $\mathrm{S}_{\mathrm{n}} \mathrm{S}$ powder was thermally stable up to a $320{ }^{\circ} \mathrm{C}$ heating temperature, as observed in the work of Shafiu et al. [29] though with slight temperature differences. This might be linked to the strong and hard phases contained as revealed by the XRD analysis. A slight weight loss was observed at a temperature range of $\left(320-670{ }^{\circ} \mathrm{C}\right)$ corresponding to the second phase. This corroborated the DTA curve fluctuations revealing the approach of thermal decomposition with a stretch in the contraction and expansion of the bonds binding the $\mathrm{S}_{\mathrm{n}} \mathrm{S}$ molecules together. Thus, the initial loss in weight $(\sim 2 \%)$ observed at this phase is presumed to be due to moisture escaping from the $S_{\mathrm{n}} \mathrm{S}$ sample [29]. A sharp degradation of the sample equivalent to $(\sim 14 \%)$ loss in weight was observed between $670{ }^{\circ} \mathrm{C}$ and $840{ }^{\circ} \mathrm{C}$ (third phase). This implies that the thermal stability of the snail shell particle decreases above $670{ }^{\circ} \mathrm{C}$, which marked the occurrence of the sample degradation. In this condition, the complete thermal decomposition of $\mathrm{S}_{\mathrm{n}} \mathrm{S}$ from calcium carbonate into calcium oxide and the liberation of carbon (iv) oxide occurred [29]. The maximum decomposition temperature of the sample was revealed by the DTA curve at $780{ }^{\circ} \mathrm{C}$. The presences of endothermic effects in the snail shell powder resulted in the evaporation and escape of volatile material at the oxidised and degradation temperatures respectively, as confirmed by the loss in weight in both stages. During the degradation stage, the snail shell which consists mainly of calcium carbonate as depicted by the EDX and XRF analysis is presumed to have undergone thermal decomposition into calcium oxide and carbon (iv) oxides, which evolved as 
gaseous material. This means that the major un-degraded constituent is presumed to include calcium oxides, some other trace substances and most likely the carbon residues materials. A further subjection of the shell sample above $840{ }^{\circ} \mathrm{C}$ resulted in no significant loss in weight up to $900{ }^{\circ} \mathrm{C}$, as examined in this study. The interpretation of this result suggests that the snail shell powder could be a potential reinforcement material in the metal matrix composite, which has a higher maximum decomposition temperature, compared to many agro-wastes reinforcement materials. The result of the TGA/DTA curve obtained was similar and in good agreement with that of Nordin et al. [29]. It was generally observed that a removal of water and the alkyl group occurred in the first phase between room temperature and $518{ }^{\circ} \mathrm{C}$. This was however accompanied by a large and drastic reduction in the weight of the seashell due to a large loss of volatile substance between 580 and $815{ }^{\circ} \mathrm{C}$ as well as the associated impurities with the $\mathrm{S}_{\mathrm{n}} \mathrm{S}$ sample.

\section{Refractories Determination}

The snail shell powder was observed to have Seger Cone No. 22, from the Orton series with an equivalent temperature of $1400{ }^{\circ} \mathrm{C}$. The implication of this is that the snail shell powder can withstand an operating temperature of $1400{ }^{\circ} \mathrm{C}$ without loss of strength at no applied load. This high refractoriness may be a result of the presence of hard oxides such as, $\mathrm{MnO}, \mathrm{CaO}, \mathrm{Cr}_{2} \mathrm{O}_{3}, \mathrm{Al}_{2} \mathrm{O}_{3}, \mathrm{ZnO}, \mathrm{SiO}_{2}$ in the snail shell. This qualifies the snail shell to be used as reinforcement material in aluminium matrix for high temperature composite materials in automotive and aerospace applications. The above result was similar to the earlier results of Madakson et al., [1] and Atuanya et al., [23] where they obtained 1500 ${ }^{0} \mathrm{C}$ as the refractory temperature of the coconut shell ash.

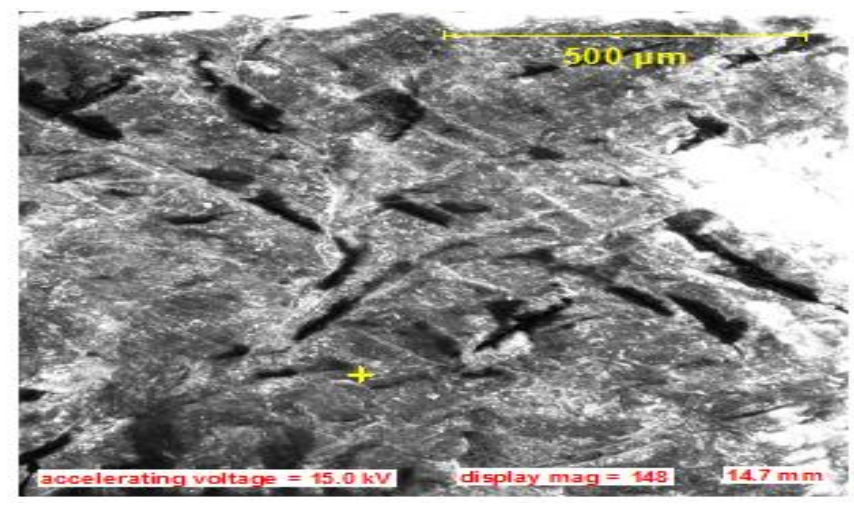

(a)

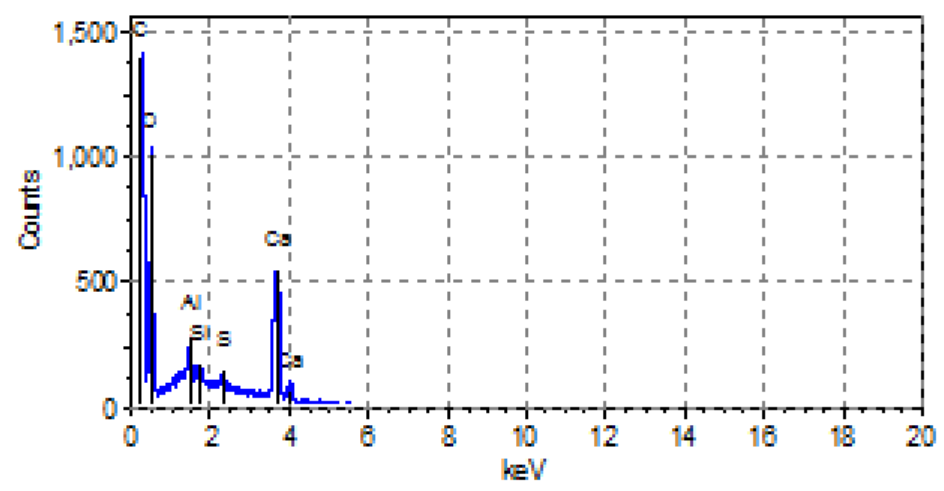

(b)

Figure 4. Snail shell compositional analysis 


\section{Snail Shell Compositional Analysis}

The results of the compositional analysis of the $\mathrm{S}_{\mathrm{n}} \mathrm{S}$ particles in Figure 4 revealed the presence of calcium, carbon, oxygen, aluminium, silicon and sulphur as the major elements, while potassium, nickel, bromine, barium, tungsten, antimony and tin are in traceable amounts. The inference from Figure 4 shows that the $\mathrm{S}_{\mathrm{n}} \mathrm{S}$ particle contains about $81 \%$ wt of calcium carbonate. The EDX of Figure 4(b) also revealed the presence of two forms of calcium elements indicating that EDX $\mathrm{S}_{\mathrm{n}} \mathrm{S}$ contains calcite and aragonite structures. The dark brown features of the surface formed major carbon atom strands responsible for the hard nature of the $S_{n} S$. Some porous spaces were conspicuously seen on its surface morphology. This may serve as the breathing channels through which an exchange of respiratory products is taking place within the snail animals. The presence of all these hard elemental compositions signalled a good potential for inclusion of this waste in the metal matrix as low cost reinforcing materials.

\section{Oxide Compositional Analysis of the Snail Shell Particle}

Table 1 shows the result of the oxide composition of the samples using the X-Ray Fluorescence (XRF) analysis. The result confirmed the presence of $\mathrm{NiO}, \mathrm{Fe}_{2} \mathrm{O}_{3}, \mathrm{MnO}$, $\mathrm{CaO}, \mathrm{Cr}_{2} \mathrm{O}_{3}, \mathrm{Al}_{2} \mathrm{O}_{3}, \mathrm{ZnO}$ and $\mathrm{SiO}_{2}$ with $\mathrm{CaO}, \mathrm{Cr}_{2} \mathrm{O}_{3}$ and $\mathrm{Fe}_{2} \mathrm{O}_{3}$ as the major constituents of the snail shell sample. The LOI represent substance loss on ignition. This may be a result of the thermal decomposition of the $S_{\mathrm{n}} S$ particles on ignition into the calcium oxide and carbon (iv) oxide liberated alongside with some other volatile substances present in the sample.

Table 1. Oxide composition of samples using X-ray fluorescence

\begin{tabular}{lllllllllllll}
\hline Element & $\mathrm{NiO}$ & $\mathrm{Fe}_{2} \mathrm{O}_{3}$ & $\mathrm{MnO}$ & $\mathrm{Cr}_{2} \mathrm{O}_{3}$ & $\mathrm{TiO}_{2}$ & $\mathrm{CaO}$ & $\mathrm{Al}_{2} \mathrm{O}_{3}$ & $\mathrm{MgO}$ & $\mathrm{ZnO}$ & $\mathrm{SiO}_{2}$ & LOI & Total \\
\hline $\mathrm{S}_{\mathrm{n}} \mathrm{S}-0$ & 0.007 & 0.051 & 0 & 0 & 0 & 66.368 & $\mathrm{LOD}$ & $\mathrm{LOD}$ & 0.001 & $\mathrm{LOD}$ & 23.573 & 100 \\
$\mathrm{~S}_{\mathrm{n}} \mathrm{S}-\mathrm{I}$ & 0 & 0.159 & 0 & 0.022 & 0 & 70.659 & LOD & LOD & 0.001 & LOD & 29.159 & 100 \\
$\mathrm{~S}_{\mathrm{n}} \mathrm{S}-\mathrm{II}$ & 0 & 0.145 & 0.01 & 0.016 & 0 & 73.509 & LOD & LOD & 0.001 & LOD & 26.319 & 100 \\
$\mathrm{~S}_{\mathrm{n}} \mathrm{S}-\mathrm{III}$ & 0 & 0.289 & 0 & 0.017 & 0 & 81.809 & LOD & LOD & 0 & LOD & 17.885 & 100 \\
\hline
\end{tabular}

It can be observed from Table 1 that $\mathrm{CaO}$ and $\mathrm{Fe}_{2} \mathrm{O}_{3}$ increased with the increasing firing temperature while the loss on ignition substances decreases with temperature. This characteristic behaviour may be a result of firing above the decomposition temperature as revealed by the TGA/DTA analysis in which a lesser weight loss of the sample was observed. $\mathrm{CaO}, \mathrm{Fe}_{2} \mathrm{O}_{3}$ and $\mathrm{Cr}_{2} \mathrm{O}_{3}$ are known to be among the hardest substances with the presence of other hard substances such as $\mathrm{NiO}, \mathrm{Al}_{2} \mathrm{O}_{3}$, $\mathrm{MnO}, \mathrm{ZnO}$ and $\mathrm{SiO}_{2}$ in traces, suggesting that the Archachatina Marginata snail shell powder can be used as a particulate reinforcement material in metal matrix composites with enhanced strength due to the possibility of the formation of a strong intermetallic bond between the matrix alloy and the hard substance snail shell powders. This result was similar to that obtained by previous researchers [1,21,23] for rice husk ash and fly ash, breadfruit hull ash and coconut shell ash, respectively.

\section{XRD Analysis of the Treated and Untreated Snail Shell $\left(\mathrm{SnS}_{\mathrm{n}}\right)$ Powder}

The XRD pattern (Figure 5a) obtained revealed that the diffraction peaks are $33.1414^{\circ}$ and $36.1959^{\circ}$ and their inter-planar distance is $2.70316 \AA$ and $2.48175 \AA$ with a relative intensity of the X-ray scattering of 32.49 and 100.00. The phases at these peaks are aragonite and calcite with a score of 67 and 21, respectively. But in the case of the treated 
$\mathrm{S}_{\mathrm{n}} \mathrm{S}$ powder, the XRD pattern (Figure $5 \mathrm{~b}$ ) obtained revealed that the diffraction peaks are $29.4165^{\circ}, 37.3547^{\circ}$ and $50.8995^{\circ}$ while their inter-planar distance is $3.0364 \AA, 2.40739 \AA$ and $1.79256 \AA$ with a relative intensity of the X-ray scattering of $100,2.40739$ and 1.28. The phases at these peaks are calcite, lime and portlandite with a score of 76, 60 and 37, respectively.

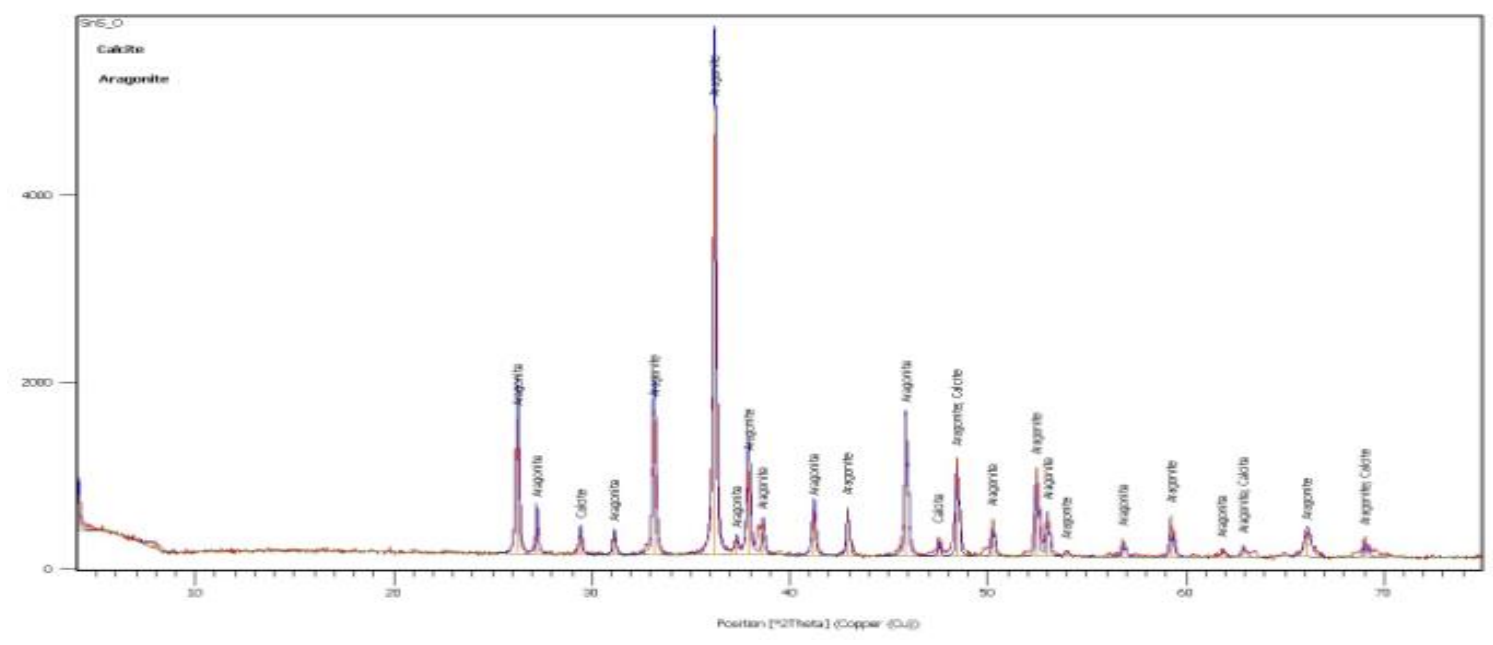

(a) Untreated $S_{n} S$ shell powder

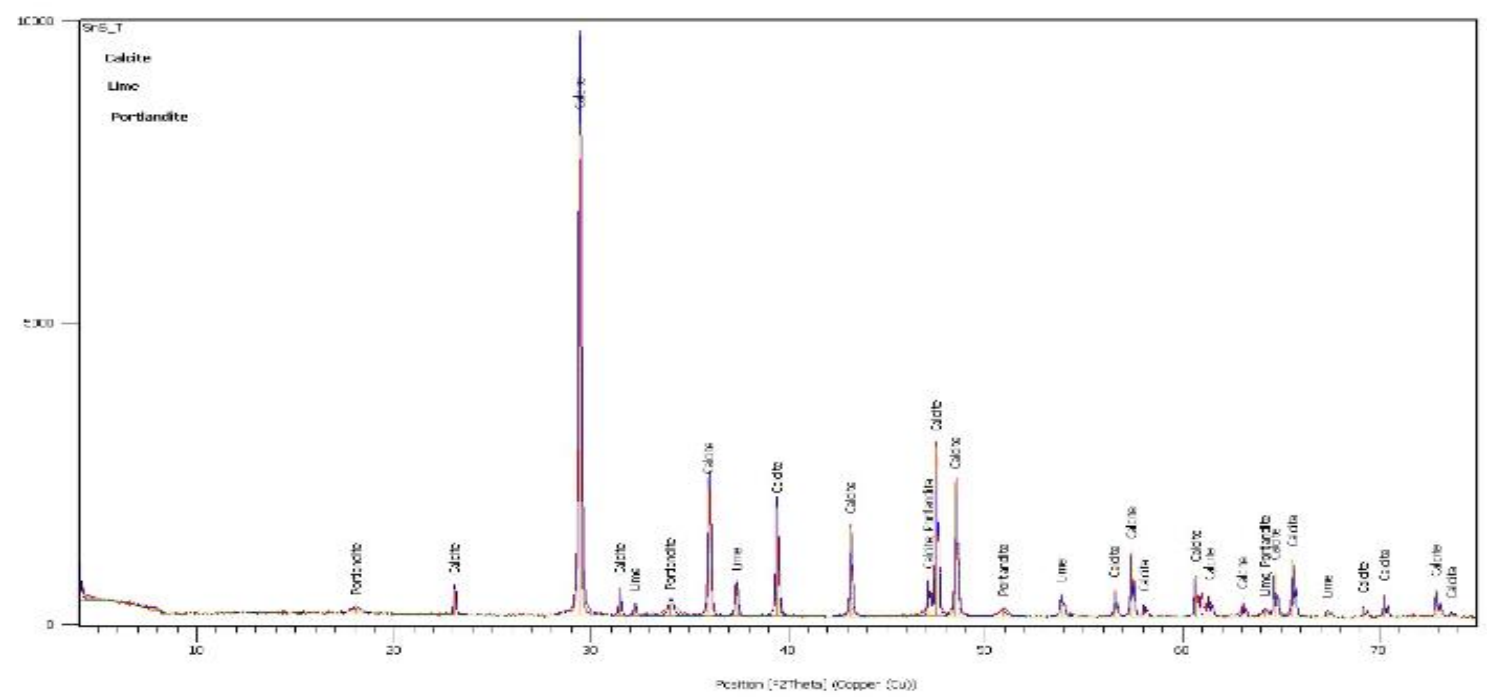

(b) Treated $\mathrm{S}_{\mathrm{n}} \mathrm{S}$ shell powder

Figure 5. XRD pattern of the untreated and treated $\mathrm{S}_{\mathrm{n}} \mathrm{S}$ shell powder

From the analysis of the XRD results above for both treated and untreated snailwaste shells, it could be observed that the major phases that exist prior to the treating process are either calcite or aragonite or both. The presence of these minerals in the shell forms the bases of the hard nature of the shells. Meanwhile, when subjected to firing at $900{ }^{\circ} \mathrm{C}$ for 3 hours, it was noticed that the aragonite minerals disappear or either alter themselves to form either calcite, lime or portlandite. This suggests that aragonite is presumed to be thermodynamically unstable and transformed into thermodynamically stable hard phases (calcite, lime and portlandite) that could possibly enhance the thermal 
mechanical resistance properties of the MMCs material when incorporated into the matrix and hence fitted for higher temperature applications such as automotive components.

\section{CONCLUSIONS}

Based on the results obtained in this work, the following conclusions can be drawn:

i) The percentage less in weight of the snail shell particles as compared to the industrial and agro-waste metal matrix reinforcement materials is $(9.4-25.9) \%$.

ii) The presence of harder phases for both treated and un-treated snail shell powder attaining their thermodynamically stability at $840{ }^{\circ} \mathrm{C}$ as confirmed by the XRF, $\mathrm{XRD}$ and TGA analysis is responsible for the hardness of the snail shell. The snail shell particle calcined at $900{ }^{\circ} \mathrm{C}$ for 3 hours produced the larger percentage of harder phases that could be used for the enhancement of properties.

iii) The light weight, presence of harder phase and high refractoriness temperature of the snail shell particle makes it a promising candidate reinforcement material for enhancing the strength and thermal resistance of MMCs applicable in automotive components such pistons and connecting rods

\section{ACKNOWLEDGEMENTS}

The authors would like to acknowledge the financial assistance received from the Association of African University (AAU) towards this research work and Department of Geology for using some of their Laboratory facilities.

\section{REFERENCES}

[1] Madakson P, Yawas D, Apasi A. Characterization of coconut shell ash for potential utilization in metal matrix composites for automotive applications. International journal of engineering science and technology. 2012;4:1190-8.

[2] Oghenevweta J, Aigbodion V, Nyior G, Asuke F. Mechanical properties and microstructural analysis of $\mathrm{Al}-\mathrm{Si}-\mathrm{Mg} /$ carbonized maize stalk waste particulate composites. Journal of King Saud University-Engineering Sciences. 2016;28:2229.

[3] Subrahmanyam A, Madhukiran J, Naresh G, Madhusudhan S. Fabrication and Characterization of Al356. 2, Rice Husk Ash and Fly Ash Reinforced Hybrid Metal Matrix Composite. International Journal of Advanced Science and Technology. 2016;94:49-56.

[4] RamakoteswaraRao V, Ramanaiah N, Srinivasa Rao M, Sarcar MMM, Kartheek G. Optimisation of process parameters for minimum volumetric wear rate on AA7075-TiC metal matrix composite. International Journal of Automotive and Mechanical Engineering. 2016;13:3669-80.

[5] Mohanty S, Routara BC. A review on machining of metal matrix composites using nanoparticle mixed dielectric in electro-discharge machining. International Journal of Automotive and Mechanical Engineering. 2016;13:3518-39.

[6] Fatchurrohman N, Sulaiman S, Sapuan SM, Ariffin MKA, Baharuddin BTHT. Analysis of a metal matrix composites automotive component. International Journal of Automotive and Mechanical Engineering. 2015;11:2531-40. 
[7] Edokpayi JN, Odiyo JO, Popoola EO, Alayande OS, Msagati TA. Synthesis and characterization of biopolymeric chitosan derived from land snail shells and its potential for $\mathrm{Pb} 2+$ removal from aqueous solution. Materials. 2015;8:8630-40.

[8] Jatto E, Asia I, Egbon E, Otutu J, Chukwuedo M, Ewansiha C. Treatment of waste water from food industry using snail shell. Academia Arena. 2010;2:32-6.

[9] Aluko F, Adisa A. Qualitative Characteristics and Suture Measurements of Two Breeds of Snail Reared in Nigeria. American Journal of Experimental Agriculture. 2014;4:1492.

[10] Meena K, Manna A, Banwait S. Jaswanti. An Analysis of Mechanical Properties of the Developed Al/SiC-MMC's. American Journal of Mechanical Engineering.1:14-9.

[11] Maleque MA, Radhi M, Rahman MM. Wear study of Mg-SiCp reinforcement aluminium metal matrix composite. Journal of Mechanical Engineering and Sciences. 2016;10:1758-64.

[12] Abu Bakar MH, Raja Abdullah RI, Md. Ali MA, Kasim MS, Sulaiman MA, Ahmad SSN, et al. Surface integrity of LM6 aluminum metal matrix composite when machined with high speed steel and uncoated carbide cutting tools. Journal of Mechanical Engineering and Sciences. 2014;6:854-62.

[13] Bhaskar HB, Sharief A. Effect of solutionizing on dry sliding wear of Al2024Beryl metal matrix composite. Journal of Mechanical Engineering and Sciences. 2012;3:281-90.

[14] Bhandare RG, Sonawane PM. Preparation of aluminium matrix composite by using stir casting method. International Journal of Engeering and Advanced Technology. 2013;3:2249-8958.

[15] Yigezu BS, Mahapatra MM, Jha PK. Influence of reinforcement type on microstructure, hardness, and tensile properties of an aluminum alloy metal matrix composite. Journal of Minerals and Materials Characterization and Engineering. 2013;1:124.

[16] Babalola P, Bolu C, Inegbenebor A, Odunfa K. Development of aluminium matrix composites: a review. Online International Journal of Engineering and Technology Research. 2014;2:1-11.

[17] Paul KK, Sijo M. Effect of stirrer parameter of stir casting on mechanical properties of aluminium silicon carbide composite. Internationa Journal Of Modern Engineering Research. 2015; 5(8):43-9

[18] Asif Iqbal AKM, Arai Y. Study on low-cycle fatigue behavior of cast hybrid metal matrix composites. International Journal of Automotive and Mechanical Engineering. 2015;11:2504-14.

[19] Ye H. An overview of the development of Al-Si-alloy based material for engine applications. Journal of Materials Engineering and Performance. 2003;12:288-97.

[20] Babić M, Stojanović B, Mitrović S, Bobić I, Miloradović N, Pantić M, et al. Wear properties of A356/10SiC/1Gr hybrid composites in lubricated sliding conditions. Tribology in Industry. 2013;35:148-54.

[21] Singh RP, Singh H. Characterization and comparison of treated and untreated rich hush ash and fly ash for metal matrix composites. International Journal of Engineering Science and Technology. 2011;3:7676-81.

[22] Adebisi AA, Maleque MA, Rahman MM. Metal matrix composite brake rotor: Historical development and product life cycle analysis. International Journal of Automotive and Mechanical Engineering. 2011;4:471-80. 
[23] Atuanya C, Aigbodion V, Nwigbo S. Characterization of breadfruit seed hull ash for potential utilization in metal matrix composites for automotive application. Peoples Journal of Science and Technology. 2012;2:1-7.

[24] Odusanya AA, Bolasodun B, Madueke CI. Property evaluation of hybrid seashell/snail shell filler reinforced unsaturated polyester composite in comparison with seashell and snail shell filler reinforced unsaturated polyester composite. The International Journal of Engineering And Science. 2014;3:80-90.

[25] Adeosun S, Akpan E, Akanegbu H. Thermo-mechanical properties of unsaturated polyester reinforced with coconut and snail shells. International Journal of Composite Materials. 2015;5:52-64.

[26] Asafa T, Durowoju M, Oyewole A, Solomon S, Adegoke R, Aremu O. Potentials of Snailshell as a Reinforcement for Discarded Aluminum Based Materials. International Journal of Advanced Science and Technology. 2015;84:1-8.

[27] Raghavendra N, Ramamurthy V. Effect of particle size and weight fraction of alumina reinforcement on wear behavior of aluminum metal matrix composites. International Journal of Innovative Research in Science, Engineering and Technology.. 2014;3:11191-8.

[28] Kh Nurul I, Zuki M, Eaqub M, Noordin MM, Loqman MY, Hanif W, et al. A novel method for the synthesis of calcium carbonate (aragonite) nanoparticles from cockle shells. Powder Tehnology. 2013; 235:70-5.

[29] Nordin N, Hamzah Z, Hashim O, Kasim FH, Abdullah R. Effect of Temperature in Calcination Process of Seashells. Malaysian Journal of Analytical Sciences. 2015;19:65-70. 